\title{
Amino acids in Arctic aerosols
}

\author{
E. Scalabrin ${ }^{1,2}$, R. Zangrando ${ }^{2}$, E. Barbaro ${ }^{1}$, N. M. Kehrwald ${ }^{2}$, J. Gabrieli ${ }^{2}$, C. Barbante ${ }^{1,2,3}$, and A. Gambaro Ga $^{1,2}$ \\ ${ }^{1}$ Department of Environmental Sciences, Informatics and Statistics, University of Venice, Ca' Foscari, 30123 Venice, Italy \\ ${ }^{2}$ Institute for the Dynamics of Environmental Processes-CNR, University of Venice, 30123 Venice, Italy \\ ${ }^{3}$ Accademia Nazionale dei Lincei, Centro “B. Segre”, 00165, Roma, Italy \\ Correspondence to: E. Scalabrin (elisa.scalabrin@unive.it)
}

Received: 3 April 2012 - Published in Atmos. Chem. Phys. Discuss.: 13 July 2012

Revised: 19 October 2012 - Accepted: 22 October 2012 - Published: 8 November 2012

\begin{abstract}
Amino acids are significant components of atmospheric aerosols, affecting organic nitrogen input to marine ecosystems, atmospheric radiation balance, and the global water cycle. The wide range of amino acid reactivities suggest that amino acids may serve as markers of atmospheric transport and deposition of particles. Despite this potential, few measurements have been conducted in remote areas to assess amino acid concentrations and potential sources. Polar regions offer a unique opportunity to investigate atmospheric processes and to conduct source apportionment studies of such compounds. In order to better understand the importance of amino acid compounds in the global atmosphere, we determined free amino acids (FAAs) in seventeen size-segregated aerosol samples collected in a polar station in the Svalbard Islands from 19 April until 14 September 2010. We used an HPLC coupled with a tandem mass spectrometer (ESI-MS/MS) to analyze 20 amino acids and quantify compounds at $\mathrm{fmol} \mathrm{m} \mathrm{m}^{-3}$ levels. Mean total FAA concentration was $1070 \mathrm{fmol} \mathrm{m}^{-3}$ where serine and glycine were the most abundant compounds in almost all samples and accounted for $45-60 \%$ of the total amino acid relative abundance. The other eighteen compounds had average concentrations between 0.3 and $98 \mathrm{fmol} \mathrm{m}^{-3}$. The higher amino acid concentrations were present in the ultrafine aerosol fraction $(<0.49 \mu \mathrm{m})$ and accounted for the majority of the total amino acid content. Local marine sources dominate the boreal summer amino acid concentrations, with the exception of the regional input from Icelandic volcanic emissions.
\end{abstract}

\section{Introduction}

Amino acids are ubiquitous compounds with an integral role in atmospheric aerosol compositions (Ge et al., 2011). Due to their low vapor pressure, amino acids are often detected in the condensed phase and are recognized as significant components of aerosols (Mandalakis et al., 2010; Violaki and Mihalopoulos, 2010; Yang et al., 2005; Zhang and Anastasio, 2003), rainwater (Cornell et al., 2003; Kieber et al., 2005; Mace et al., 2003b), fog (Zhang and Anastasio, 2001) and dew water (Scheller, 2001). Despite their abundance, the fate and properties of atmospheric amino acids are poorly understood. Amino acids can be involved in cloud formation or act as ice-forming nuclei due to their hygroscopicity (Szyrmer and Zawadzki, 1997) and affect atmospheric radiation balance and climate (Chan et al., 2005). Some compounds, such as methionine and tryptophan, can quickly react with atmospheric oxidants and influence atmospheric chemistry and air pollutant scavenging (McGregor and Anastasio, 2001; Zhang and Anastasio, 2003). Amino acids are able to react with glyoxal to produce secondary aerosols (De Haan et al., 2009). L-methionine oxidation is hypothesized to lead to ultrafine particle formation in the summer Arctic atmosphere (Leck and Bigg, 1999). Free amino acids (FAAs) are particularly bioavailable and therefore may also significantly contribute to organic nitrogen and carbon in atmospheric depositions (Cornell et al., 2003; Zhang et al., 2002) and are a source of nutrients to marine ecosystems (Wedyan and Preston, 2008).

Several sources affect atmospheric amino acids thereby complicating the possibility of identifying their origin. Matsumoto and Uematsu (2005) verified that long-range transport of land-derived aerosols can largely contribute to amino acids concentrations in the North Pacific. However, Wedyan 
and Preston (2008) argue that the positive correlation between amino acid concentrations in aerosols and surface water particulates in the South Atlantic Ocean provide evidence of a marine origin. Proteinaceous material associated with terrestrial dust, phytoplankton production, bacteria and biological degradation (Dittmar et al., 2001) is likely primary sources of free and combined amino acids (Ge et al., 2011). Amino acids are also detected in volcanic emissions (Mukhin et al., 1978) and tobacco smoke and therefore may be associated with combustion-derived aerosols. This contribution of combustion processes to amino acids is supported by the correlation $\left(r^{2}=0.7, p<0.001\right)$ between glycine and elemental carbon (EC) (Violaki and Mihalopoulos, 2010).

Due to their distance from emission sources and their naturally low aerosol concentrations, Polar regions are excellent natural laboratories to conduct source apportionment studies of such compounds. Antarctica is isolated from other continents by the sea, and is often considered a pristine location and a baseline against which other aerosol concentrations can be compared. During the Arctic summer, aerosol chemical compositions are strongly affected by local natural emission sources and aerosol concentrations are comparable to the Antarctic flux (Quinn et al., 2007). During the winter months, the Arctic is often influenced by the transport of polluted air from the Eurasian landmass. This increased input of FAAs from Eurasia has the potential to alter regional bioavailability of organic nitrogen as well as changing the formation of cloud condensation nuclei, and by extension, regional cloudiness and precipitation.

In this study we examine FAAs at the remote Gruvenbadet Station, Ny-Ålesund $\left(78^{\circ} 92^{\prime} \mathrm{N}, 11^{\circ} 90^{\prime} \mathrm{E}\right)$ in the Svalbard Islands. Here, we analyze size-segregated aerosol samples of the following FAAs: phenilalanine (Phe), threonine (Thr), leucine (Leu), isoleucine (Ile), methionine (Met), tyrosine (Tyr), valine (Val), proline (Pro), 3-hydroxyproline (3-Hyp), 4-hydroxyproline (4-Hyp), alanine (Ala), glutamic acid (Glu), glutammine (Gln), serine (Ser), asparagine (Asn), aspartic acid (Asp), cysteine (Cys), glycine (Gly), methionine sulfoxide (MetSO), and methionine sulfone $\left(\mathrm{MetSO}_{2}\right)$. The aim of this study is to investigate the occurrence and concentration levels of amino acidic compounds in the Arctic region during the boreal summer to identify potential emission sources and the relative contributions of regional and local sources. Amino acids might be used as markers for bioderived aerosols and the different compound reactivity may be useful to determine aerosol age. The analysis of different aerosol size classes permits to highlight particular amino acid size distribution tendencies and may help the source apportionment study. We examine if summer FAAs include contributions from long-range transport which may overwhelm the relatively pristine local signal with implications for the regional radiation balance and biogeochemical dynamics.

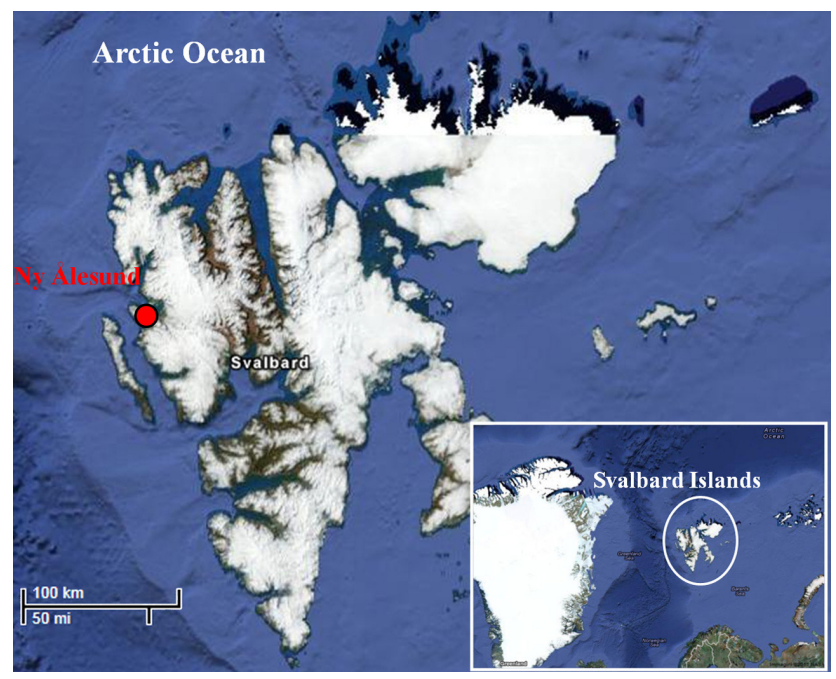

Fig. 1. Sampling location of Arctic aerosols at Ny-Ålesund, Svalbard Islands.

\section{Materials and methods}

\subsection{Sample collection}

Seventeen aerosol samples were collected at the Gruvenbadet Station, Ny-Ålesund during the boreal summer from 19 April to 14 September 2010 (Fig. 1). Sampling periods varied between 131 and $246 \mathrm{~h}$. The aerosols were collected on glass fiber filters $(150 \times 143 \mathrm{~mm}$; FilterLab, Filtros Anoia S.A., Espana) with 10 parallel perforated slots. A five-stage high volume cascade impactor Model TE-235 equipped with a TE$6070 \mathrm{PM}_{10}$ size selective head (Tisch Environmental Inc.) was used at a flow rate of $68 \mathrm{~m}^{3} \mathrm{~h}^{-1}$. This sampler allows the collection of airborne particles in five size classes (aerodynamic diameter ranges of $10-7.2 \mu \mathrm{m}, 7.2-3.0 \mu \mathrm{m}, 3.0$ $1.5 \mu \mathrm{m}, 1.5-0.95 \mu \mathrm{m}, 0.95-0.49 \mu \mathrm{m})$ and one background filter that collects particles smaller than $0.49 \mu \mathrm{m}$. The slotted filters collected aerosol particles in the $10-0.49 \mu \mathrm{m}$ size range while the background filters collected all particles smaller than the cut-off size of the last impactor stage $(<0.49 \mu \mathrm{m})$. In order to check for possible contamination, we collected six blank samples by placing filters in the holder when the instrument was turned off. All filters were pre-combusted $(4 \mathrm{~h}$ in a $400^{\circ} \mathrm{C}$ in a muffle furnace) before sampling and stored at $-20^{\circ} \mathrm{C}$ wrapped in two aluminum foils until analysis.

\subsection{Reagents and standard solutions}

Ultra grade methanol $(\mathrm{MeOH})$ and acetonitrile $(\mathrm{ACN})$ were purchased from Romil LTD, (Cambridge, UK). Ammonium acetate $(\geq 99 \%)$ and formic acid $(98 \%)$ were obtained from Fluka (Sigma-Aldrich ${ }^{\circledR}$, Buchs, Switzerland) and hydrochloric acid $37 \%$ ACS was supplied by Carlo Erba. Ultrapure water $(18.2 \mathrm{M} \Omega \mathrm{cm}, 0.01 \mathrm{TOC})$ was produced using a Purelab Ultra System (Elga, High Wycombe, UK). 
The isotopically-labeled ${ }^{13} \mathrm{C}$ amino acids $\left(L-\left[{ }^{13} \mathrm{C}_{3}\right]\right.$ alanine, $L-\left[{ }^{13} \mathrm{C}_{4}\right]$ aspartic acid, $L-\left[{ }^{13} \mathrm{C}_{5}\right]$ glutamic acid, and $L$ $\left[{ }^{13} \mathrm{C}_{6}\right]$ arginine; purity of $98 \%$ ) were purchased from SigmaAldrich ${ }^{\circledR}$ and $\left[{ }^{13} \mathrm{C}_{1}\right]$ leucine, $L-\left[{ }^{13} \mathrm{C}_{1}\right]$ phenylalanine, $L$ $\left[{ }^{13} \mathrm{C}_{1}\right]$ proline, and $L-\left[{ }^{13} \mathrm{C}_{1}\right]$ valine, purity $\geq 98 \%$, were obtained from Cambridge Isotope Laboratories Inc. (Andover, MA).

\subsection{Sample processing}

To avoid contamination from laboratory air particles, samples were handled under a laminar flow bench (class 100). To maximize the extraction efficiency, each filter was broken into small pieces with a diameter of $5 \mathrm{~mm}$, placed in a $50 \mathrm{~mL}$ conical flask, spiked with $100 \mu \mathrm{L}$ of isotopically-labeled ${ }^{13} \mathrm{C}$ amino acid standard solutions (concentration ranges between 0.5 to $25 \mathrm{ng}_{\mu \mathrm{L}}^{-1}$ ) and then extracted twice in $\mathrm{MeOH}$ for $14 \mathrm{~min}$ by ultrasonication. Extraction volumes were $10 \mathrm{~mL}$ and then $5 \mathrm{~mL}$ for each ultrasonic cycle for the slotted filters and $35 \mathrm{~mL}$ and $5 \mathrm{~mL}$ for the background $(<0.49 \mu \mathrm{m})$ filters. The extracts were then unified and filtrated through a $0.45 \mu \mathrm{m}, \varnothing 25 \mathrm{~mm}$ PTFE filter before analysis.

\subsection{HPLC ESI MS/MS}

Sample analysis methods of amino acid and methionine oxidation products are described in detail by Zangrando et al. (2010) and Barbaro et al. (2011). Briefly, an Agilent 1100 Series HPLC System (Waldbronn, Germania) equipped with a binary pump, vacuum degasser, and autosampler was coupled with an ESI electrospray ion source and an API 4000 Triple Quadrupole Mass Spectrometer (Applied Biosystem/MDS SCIEX, Concord, Ontario, Canada). Chromatographic separation was performed using a $2.1 \times 150$ $\mathrm{mm}, 100 \AA$ ZIC-HILIC column coupled to a ZIC-HILIC Guard $5 \mu \mathrm{m}, 20 \times 2.1 \mathrm{~mm}$ (SeQuant AB, Umea, Sweden) guard column with a mobile phase gradient elution consisting of $5 \mathrm{mM}$ ammonium acetate aqueous buffer-pH 4.00 (eluent A) and ACN with $100 \mu \mathrm{L}$ of formic acid (eluent B). The ESI was operated in positive polarity during amino acid analysis and in alternate polarity during analysis of methionine oxidation products. Data were acquired in multiple reactions monitoring (MRM) mode, which permits the detection of selected fragments with high selectivity and sensitivity. Internal standards were used to quantify the amino acids by isotope dilution and the results were corrected by evaluating instrumental response factors.

\subsection{Statistical methods}

Hierarchical cluster analysis (HCA) and factor analysis (FA) were performed using Statistica 8.0 (StatSoft, Inc., 2007). Only variables which had values over the limit of detection (LOD) in at least half the cases were considered significant for statistical analysis. To ensure that the analyte concentrations were sufficiently higher than the background contami-

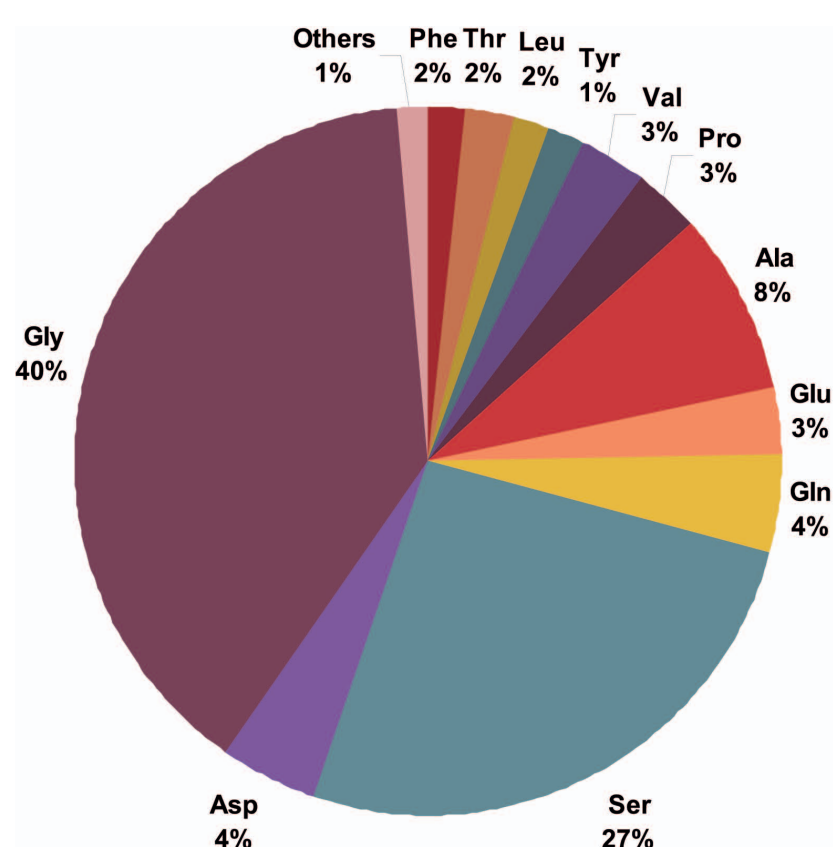

Fig. 2. Mean relative abundances of amino acids in total samples. The category others includes: Met, 3Hyp, 4Hyp, Asn and Cys.

nation, the LOD was calculated for each compound, for both background $(<0.49 \mu \mathrm{m})$ filters and slotted $(0.49-10 \mu \mathrm{m})$ filters as three times the standard deviation of the blanks (MacDougall and Crummett, 1980). The LOD values in terms of fmolm $^{-3}$ were calculated using the averaged sampling volume, $11982 \mathrm{~m}^{3}$ and $11613 \mathrm{~m}^{3}$ for slotted and background filters respectively. The LOD value was used for non-detectable concentrations (Table 1). HCA was performed using Ward's algorithm and Euclidean distances as clustering criteria. In FA only factors with eigenvalues greater than 1 were considered and were subject to a varimax rotation.

\section{Results and discussion}

\subsection{Amino acid size distributions}

Of the 17 collected samples, 9 were analyzed in all 6 of the size ranges. For the other 8 samples, only the background $(<0.49 \mu \mathrm{m})$ filters were analyzed. All amino compounds were detected in at least 1 sample and at least 1 amino acid was present in all samples. The total FAA concentrations in the 9 samples, obtained from the sum of the 6 size distributions, ranged between 592 and $4725 \mathrm{fmol} \mathrm{m}^{-3}$. Samples collected during the first week of May have the highest concentrations, with total FAA concentrations double than those collected from 6-16 June. The dominant compounds were Gly and Ser which together accounted for 45$60 \%$ of the total amino acid content. Gly was not detected in samples collected from 20-27 July and from 10-17 August 2010 yet Ser was present in all of these samples. Other 
Table 1. Limits of detection (LOD),ng ( $\mathrm{fmolm}^{-3}$ ), of single amino compounds in aerosol samples and average concentration in the blank samples, ng $\left(\mathrm{fmolm}^{-3}\right)$.

\begin{tabular}{|c|c|c|c|c|}
\hline & \multicolumn{2}{|c|}{ Background filters } & \multicolumn{2}{|c|}{ Slotted filters } \\
\hline & LOD & Blank samples & LOD & Blank samples \\
\hline Phe & $10.7(5.6)$ & $23.5(12.3)$ & $21.0(10.7)$ & $43.8(2.2)$ \\
\hline Thr & $1.8(1.3)$ & $15.6(11.3)$ & $14.0(9.8)$ & $29.1(2.1)$ \\
\hline Leu & $5.6(3.7)$ & $24.4(16.0)$ & $13.0(8.3)$ & $35.8(6.7)$ \\
\hline Ile & $4.6(3.0)$ & $12.5(8.2)$ & $11(7.0)$ & $17(3.9)$ \\
\hline Met & $0.4(0.2)$ & $1.5(0.8)$ & $0.5(0.2)$ & $1.5(0.3)$ \\
\hline Tyr & $5.1(2.4)$ & $10.7(5.1)$ & $18.0(8.2)$ & $27.9(3.8)$ \\
\hline Val & $6.9(5.2)$ & $24.0(17.9)$ & $16.0(11.6)$ & $30.9(12.7)$ \\
\hline 3-Нур & $2.8(1.8)$ & $18.8(12.3)$ & $6.0(3.8)$ & $2.7(0.1)$ \\
\hline Pro & $2.5(1.9)$ & $35.3(26.4)$ & $6.0(4.3)$ & $38.7(20.9)$ \\
\hline 4-Нур & $2.5(1.6)$ & $1.3(0.9)$ & $0.8(0.5)$ & $1.4(0.1)$ \\
\hline Ala & $4.2(4.0)$ & $35.4(34.2)$ & $2.0(1.9)$ & $24.7(7.6)$ \\
\hline Glu & $3.6(2.1)$ & $2.6(1.5)$ & $9.0(5.1)$ & $24.0(1.9)$ \\
\hline Gln & $0.1(0.1)$ & $4.7(2.8)$ & $4.0(2.3)$ & $8.5(0.7)$ \\
\hline Ser & $2.7(2.2)$ & $76.5(62.7)$ & $8 \times 10^{1}\left(6 \times 10^{1}\right)$ & $9 \times 10^{1}\left(5 \times 10^{1}\right)$ \\
\hline Asn & $5.4(3.5)$ & $14.8(9.6)$ & $8.0(5.0)$ & $12.9(3.9)$ \\
\hline Asp & $4 \times 10^{1}\left(2 \times 10^{1}\right)$ & $1 \times 10^{1}\left(7 \times 10^{1}\right)$ & $7.2 \times 10^{2}\left(4.5 \times 10^{2}\right)$ & $2.85 \times 10^{3}\left(2.7 \times 10^{1}\right)$ \\
\hline Cys & $16(11)$ & $34(25)$ & $5.0(3.4)$ & $5.7(0.7)$ \\
\hline Gly & $1.2 \times 10^{2}\left(1.4 \times 10^{2}\right)$ & $7 \times 10^{1}\left(8 \times 10^{1}\right)$ & $8 \times 10^{1}\left(8 \times 10^{1}\right)$ & $6 \times 10^{1}\left(2 \times 10^{1}\right)$ \\
\hline MetSO & $1.5(0.7)$ & $0.9(0.5)$ & $0.7(0.4)$ & $0.54(0.3)$ \\
\hline $\mathrm{MetSO}_{2}$ & $0.8(0.3)$ & $0.4(0.2)$ & $0.2(0.1)$ & $0.19(0.09)$ \\
\hline
\end{tabular}

Table 2. Amino acid concentration ranges in the single stages of the completely analyzed samples $\left(\mathrm{fmol} \mathrm{m}^{-3}\right)$.

\begin{tabular}{|c|c|c|c|c|c|c|}
\hline \multicolumn{7}{|c|}{ Aerosol size fractions $(\mu \mathrm{m})$} \\
\hline & $10-7.2$ & $7.2-3.0$ & $3.0-1.5$ & $1.5-0.95$ & $0.95-0.49$ & $<0.49$ \\
\hline Phe & N.D. -44 & N.D.-27 & N.D. -31 & $<\mathrm{LOD}$ & N.D.-18 & N.D. -49 \\
\hline Thr & N.D. -44 & N.D. -29 & N.D. -36 & $<$ LOD & N.D. -20 & $3-52$ \\
\hline Leu & N.D. -32 & N.D. -20 & N.D. -21 & $<$ LOD & N.D. -37 & N.D. -37 \\
\hline Ile & N.D. -30 & N.D. -16 & N.D. -17 & $<$ LOD & N.D. -31 & N.D. -35 \\
\hline Met & N.D. -1.96 & N.D. -1.49 & N.D. -1.60 & $<$ LOD & N.D. -4.79 & N.D. -2.79 \\
\hline Tyr & N.D. -23 & N.D. -13 & N.D. -14 & $<$ LOD & N.D.-30 & N.D. -40 \\
\hline Val & N.D. -49 & N.D. -25 & N.D.-27 & $<$ LOD & N.D. -49 & N.D. -78 \\
\hline Pro & N.D. -30 & N.D. -19 & N.D. -18 & $<$ LOD & N.D. -40 & $23-72$ \\
\hline 3-Нyp & $<$ LOD & $<$ LOD & $<$ LOD & $<$ LOD & $<\mathrm{LOD}$ & N.D. -81.8 \\
\hline 4-Нyp & $<\mathrm{LOD}$ & $<$ LOD & $<$ LOD & $<$ LOD & $<$ LOD & N.D. -3.7 \\
\hline Ala & N.D. -99 & N.D. -52 & N.D. -66 & $<$ LOD & N.D. -144 & $28-245$ \\
\hline Glu & N.D. -24 & N.D. -45 & N.D. -21 & $<$ LOD & N.D.-37 & N.D. -55 \\
\hline Gln & N.D. -36.6 & N.D.-125.7 & N.D. -25.4 & N.D. -3.0 & N.D. -14.0 & $0.26-37.22$ \\
\hline Ser & N.D. $-3.4 \times 10^{2}$ & N.D. $-1.9 \times 10^{2}$ & N.D. $-2.0 \times 10^{2}$ & $<$ LOD & N.D. $-4.5 \times 10^{2}$ & 104-611 \\
\hline Asn & $<\mathrm{LOD}$ & $<$ LOD & $<\mathrm{LOD}$ & $<\mathrm{LOD}$ & N.D. -13 & N.D. -63 \\
\hline Asp & $<$ LOD & N.D.-77 & N.D. -56 & N.D. -69 & N.D. -165 & N.D. -275 \\
\hline Cys & $<$ LOD & $<$ LOD & $<$ LOD & $<\mathrm{LOD}$ & $<\mathrm{LOD}$ & N.D. -32 \\
\hline Gly & N.D. $-3.2 \times 10^{2}$ & N.D. $-1.1 \times 10^{2}$ & N.D. $-1.2 \times 10^{2}$ & N.D. $-1.1 \times 10^{2}$ & N.D. $-6.1 \times 10^{2}$ & N.D. $-1.25 \times 10^{3}$ \\
\hline MetSO & $<$ LOD & $<\mathrm{LOD}$ & N.D-1.4 & $<\mathrm{LOD}$ & N.D-3.6 & N.D. -4.7 \\
\hline$\Sigma$ FAAs & N.D. $-2.2 \times 10^{2}$ & N.D. $-1.3 \times 10^{2}$ & N.D. $-1.1 \times 10^{2}$ & N.D. $-3 \times 10^{1}$ & N.D. $-3.0 \times 10^{2}$ & $1.6 \times 10^{2}-3.03 \times 10^{3}$ \\
\hline
\end{tabular}

relevant compounds include Ala, Glu and Gln, which occurred in each sample and consisted of up to $15 \%$ of the total amino acid concentrations. The relative distribution of FAAs in the total aerosol samples is reported in Fig. 2 and single amino acid concentration ranges are shown in Table 2. Our amino acid relative abundances are consistent with observations by Matsumoto and Uematsu (2005) for remote areas of the North Pacific Ocean and for the Atlantic Ocean (Wedyan 


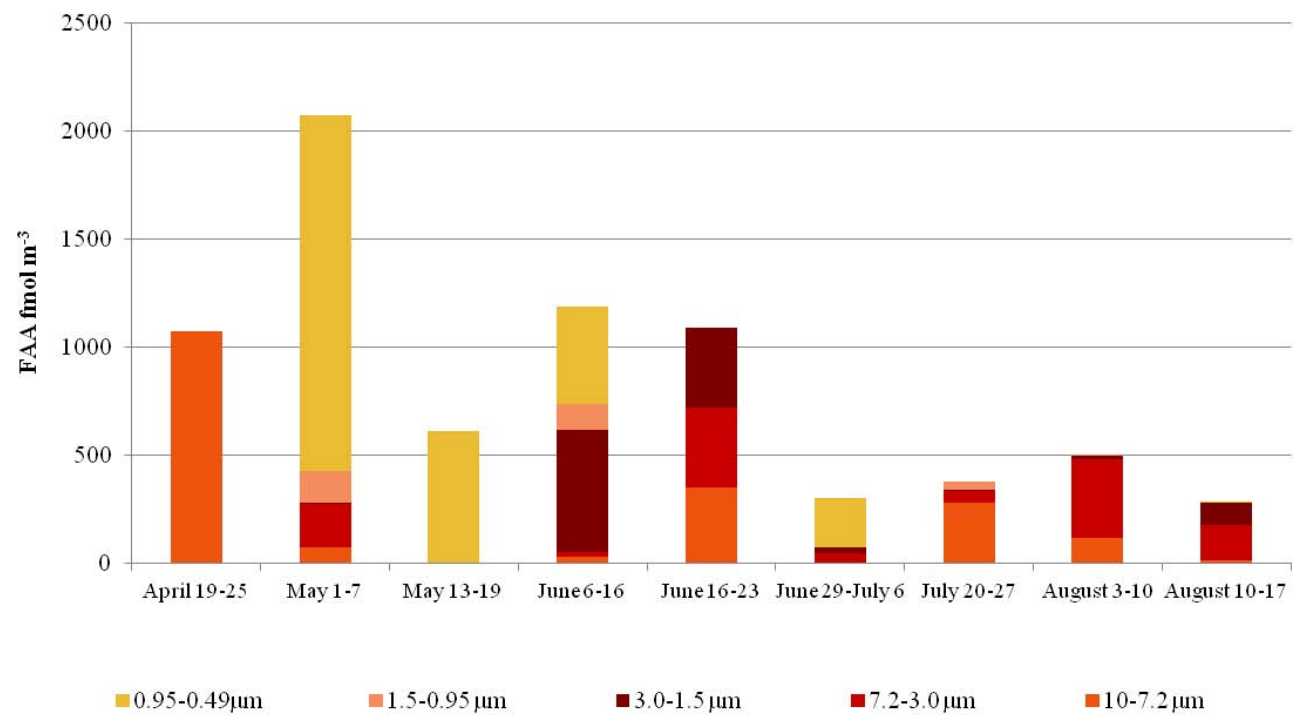

Fig. 3. Total amino acid size distributions in the five stages of completely analyzed samples.

and Preston, 2008). These studies report Gly, Ser and Ala as the major FAA compounds in their samples. Violaki and Mihalopoulos (2010) observed high Gly and Ser abundances, $54 \%$ and $16 \%$ respectively, in ultrafine particulate matter in the Eastern Mediterranean Sea. Lower levels of these two compounds existed in coastal areas (Kuznetsova et al., 2005; Mace et al., 2003b) and in land-derived aerosols (Barbaro et al., 2011; Mace et al., 2003a; Zhang and Anastasio, 2003). In general, single amino acids have similar profiles in all samples.

The amino acid concentrations in our samples are less than those recorded in previous studies of FAAs in marine aerosols in remote areas, where studies by Matsumoto and Uematsu (2005) and Gorzelska and Galloway (1990) determine respective average concentrations of $10.7 \mathrm{pmol} \mathrm{m}^{-3}$ and $3 \mathrm{pmol} \mathrm{m}^{-3}$. Marine samples that were more affected by terrestrial emissions result in higher average concentrations. Wedyan and Preston (2008) reported an average FAA concentration of $0.2 \mathrm{nmol} \mathrm{m}^{-3}$ in the Atlantic Ocean, Barbaro et al. (2011) observed a mean of $334 \mathrm{pmol} \mathrm{m}^{-3}$ in the Venice Lagoon (Italy), Mandalakis et al. (2010) determined an average of $172 \mathrm{pmol} \mathrm{m}^{-3}$ in Finokalia (Greece) and Mace et al. $(2003 \mathrm{~b}, \mathrm{c})$ found ranges of $15-160 \mathrm{pmol} \mathrm{m}^{-3}$ and $30-800 \mathrm{pmol} \mathrm{m}^{-3}$ in Tasmania (Australia) and in Erdemli (Turkey), respectively (in Mandalakis et al., 2011). Amino acids are usually present in the finest aerosol fractions $<2.5 \mu \mathrm{m},<1 \mu \mathrm{m}$ and $<0.5 \mu \mathrm{m}$ (Matsumoto and Uematsu, 2005; Violaki and Mihalopoulos, 2010; Milne and Zika, 1993). Mace et al. (2003b) determined a bimodal size distribution in marine aerosol, between 3.5-7.2 $\mu \mathrm{m}$ and $0-0.95 \mu \mathrm{m}$ in Tasmania (Australia) and hypothesize that this distribution is due to the presence of virus and bacteria in aerosol samples. They attributed the fine mode $(<1 \mu \mathrm{m})$ to the presence of organic surfactants or to the influence of gas-to-particle conversions and the coarse mode ( $>1 \mu \mathrm{m}$ ) to the presence of live species, especially bacteria that typically range in length from 3.7 to $7.5 \mu \mathrm{m}$ in tropical areas or 0.5 to $3 \mu \mathrm{m}$ in the Arctic (Leck and Bigg, 2008). Our samples agree with Milne and Zika (1993) as the majority of the background filters $(<0.49 \mu \mathrm{m})$ accounted for more than a half of the total amino acid concentrations although some samples showed high amino acid levels in other aerosol fractions (Fig. 3).

The highest amino acid concentrations in the $10-0.49 \mu \mathrm{m}$ size range were detected in the sample collected from 1-7 May where the largest five fractions accounted for the $35 \%$ of the total sample FAAs. This sample showed a high contribution of the $1.5-0.95 \mu \mathrm{m}$ fraction which contains all the amino compounds, except for Cys; the 13-19 May sample showed a similar contribution from this fraction, which represents the $100 \%$ of FAAs abundance in the five largest aerosol fractions. The lowest amino acid concentrations in the $10-0.49 \mu \mathrm{m}$ size range were found in the samples collected from July to August (29 June-6 July, 20-27 July, 3-10 August, 10-17 August) which showed the major contribution of the two largest aerosol fractions, 10-7.2 and 7.2-3.0 $\mu \mathrm{m}$. In samples collected between 19-25 April and 20-27 July, the largest particles $(10-7.2 \mu \mathrm{m})$ were the most enriched in amino compounds and had higher concentrations than their respective background filters $(<0.49 \mu \mathrm{m})$. This enrichment is likely due to a local source of amino acids as large particles are not conducive to long-range transport. Local sources include bubble bursting processes on the sea surface (Leck and Bigg, 2007 and references within) which generally lead to particle production in the range of a few micrometers.

Weinbruch et al., 2012 reported that the sea salt particles represent the 30-90\% in the Arctic aerosol coarse fraction $(>0.5 \mu \mathrm{m})$ collected during summer season at the Zeppelin station; on the contrary fine particles $(<0.5 \mu \mathrm{m})$ appear to be 
Table 3. Mean, median, maximum and minimum values of amino acids in Arctic background $(<0.49 \mu \mathrm{m})$ filters $\left(\mathrm{fmol} \mathrm{m}^{-3}\right)$.

\begin{tabular}{lcccc}
\hline & Mean & Median & Max & Min \\
\hline Phe & 14 & 10 & 49 & $<$ LOD \\
Thr & 19 & 11 & 52 & 3 \\
Leu & 14 & 10 & 37 & $<$ LOD \\
Ile & 10 & 8 & 35 & $<$ LOD \\
Met & 0.3 & $<$ LOD & 3 & $<$ LOD \\
Tyr & 19 & 17 & 46 & $<$ LOD \\
Val & 34 & 32 & 78 & $<$ LOD \\
3-Hyp & 5 & $<$ LOD & 82 & $<$ LOD \\
Pro & 44 & 43 & 106 & 15 \\
4-Hyp & 0.3 & $<$ LOD & 4 & $<$ LOD \\
Ala & 98 & 87 & 245 & 28 \\
Glu & 22 & 22 & 55 & $<$ LOD \\
Gln & 22 & 16 & 75 & 0.3 \\
Ser & $3 \times 10^{2}$ & 262 & 668 & 105 \\
Asn & 6 & $<$ LOD & 63 & $<$ LOD \\
Asp & $3 \times 10^{1}$ & $<$ LOD & 275 & $<$ LOD \\
Cys & 1 & $<$ LOD & 32 & $<$ LOD \\
Gly & $4 \times 10^{2}$ & 396 & 1254 & $<$ LOD \\
MetSO & 3.1 & $<$ LOD & 4.7 & $<$ LOD \\
EFAAs & $1.1 \times 10^{3}$ & 916 & 3158 & 151 \\
\hline & & & &
\end{tabular}

much more influenced by secondary and mixed aerosol containing organics. Similar results were obtained by Hillamo et al., 2001 who pointed out a $2 \mu \mathrm{m}$ mode for primary seasalt particles in the Arctic Ocean during summer season and a $0.1-0.3 \mu \mathrm{m}$ Aitken mode for secondary particles associated mainly with biogenic emissions. Moreover, Hawkins and Russell, 2010 observed that the size range of atmospheric proteinaceous and amino acidic particles in the Arctic Ocean is mainly $1.5-6.9 \mu \mathrm{m}$. All these studies support the hypothesis that larger aerosol fractions in the Arctic may be mainly related to bubble bursting phenomenon while fine and ultrafine particles are much more affected by atmospheric transport and reactions, including ageing.

The two samples collected from 6-16 and 16-23 June, contain amino acid distributions in which the five size fractions are more complex than in the other samples. In the 6-16 June sample the 1.5-3.0 $\mu \mathrm{m}$ size fraction contains all of the measured compounds except for Cys while the 0.49-0.95 $\mu \mathrm{m}$ size fraction contains Met, Ala, Glu, Gln, Asp, Gly. All size fractions of the 6-16 June sample contained Gly and Glu. In the 16-23 June sample all amino acids except for Asp, Gly, 3- and 4-Hyp had similar concentrations in the three largest size fractions but were not present in the smallest size fractions.

The analysis of different aerosol fractions allows us to point out some particular tendency in the single compound distributions. Gln, which is one of the most abundant compounds in the largest aerosol fractions, tends to accumulate in preference in the second stage $(3.0-7.2 \mu \mathrm{m})$, where repre- sents on average the $5 \%$ of the total amino acid content. The same is observed for Glu, which relative abundance in the second stage is $3 \%$, and whose trend appears very similar to Gln one in all aerosol fractions. This finding could suggest a relation between the two amino acids source: the oxidation of the amide Gln, indeed, might lead to the formation of the carboxylic acid Glu in atmosphere (Milne and Zika, 2003; Ge et al., 2011).

\subsection{Amino acids and sources in ultrafine aerosols $(<0.49 \mu \mathrm{m})$}

Of the measured aerosol size fractions, the highest amino acid concentrations were detected in the background filters $(<0.49 \mu \mathrm{m})$. FAA total concentrations in these filters varied between 212 and $2521 \mathrm{fmol} \mathrm{m}^{-3}$. Gly and Ser were the most abundant compounds in almost all samples and their relative concentrations were generally higher (49-79\%) than in the total samples. Ala and Pro were detected in all samples and had generally high levels ranging between 28 and $382 \mathrm{fmol} \mathrm{m}^{-3}$ and 14 and $115 \mathrm{fmol} \mathrm{m}^{-3}$, respectively. Other relevant compounds include Gln, Thr, Val and Glu that were present in every sample. The mean, median, maximum and minimum concentrations of each compound in the $<0.49 \mu \mathrm{m}$ filters are reported in Table 3. Only two samples, collected from 1-7 May and from 13-19 May, showed high FAA concentrations in the $0.95-0.49 \mu \mathrm{m}$ size range and both samples contain high amino acid levels in the background filters ( $1254 \mathrm{fmol} \mathrm{m}^{-3}$ and $2521 \mathrm{fmol} \mathrm{m}^{-3}$ respectively).

The 1-7 and 13-19 May samples were affected by specific sources that are outside of the normal occurrences for the sample site. During 1-7 May a fire drill was conducted near the sampling station, producing large quantities of smoke which likely interfered with sampling. High concentrations of almost all amino acids were detected in the two smallest size ranges $(0.95-0.49 \mu \mathrm{m}$ and $<0.49 \mu \mathrm{m})$. Glu, Gln, Asp and Gly were detected also in the $10-7.2 \mu \mathrm{m}, 7.2-3.0 \mu \mathrm{m}$, $3.0-1.5 \mu \mathrm{m}$ size ranges. These results suggest biomass burning as a source for amino compounds, as previously indicated by Schmeltz and Hoffmann (1977) who reported the occurrence of Ala, Asp, Gln and Gly in tobacco smoke and by Mace et al. (2003a), who identified amino acids in biomass burning aerosols collected in the Amazon basin.

Volcanic eruptions can release FAAs including Gly, Ser, Phe, Thr and Pro (Mukhin et al., 1978). The FAAs in the ultrafine particle fraction of the 13-19 May sampling are likely due to the 3-23 May 2010 eruption of the Icelandic Eyjafjallajökull volcano. We argue that ash transported from the volcanic plume affected amino acid concentrations in the 1319 May but not in the 1-7 May, the 7-13 May and 25-31 May samples based on the movement of air masses arriving at the Svalbard sample site. We considered for all samples the back trajectories at altitude of $500 \mathrm{~m}$ a.s.l. (Figs. S1, S2, S3, S4 in the Supplement), which correspond to the elevation of the Zeppelin Mountain, the highest neighboring mount; we 
reported in Fig. 4a, b, c, d the trajectories calculated for all the samples collected during the volcanic event. The 13-19 May air plumes (Fig. 4c) originate from areas neighboring the Eyjafjallajökull volcano and derive from higher altitude $(\approx 1500 \mathrm{~m}$ a.s.l.), suggesting that the elevated ultrafine FAAs in this sample, might represent this volcanic input. Also in the sample collected between the 1-7 May the back trajectories could indicate air masses transport from the Iceland to the Svalbard during the 7th of May. In this case, however, the altitude of the trajectory can't encompass the atmospheric height of the volcanic plume (Petersen, 2010). No clear evidence of contribution from the Eyjafjallajökull eruption to the other samples appears from the back trajectories (Fig. 4b, c).

As the Eyjafjallajökull volcano continued erupting until 23 May, the transport time and path of volcanic aerosols from Eyjafjallajökull are such that it is possible the eruption at least partly contributes to FAA concentrations between 25 to 31 May 2010 (Fig. 5), which are elevated with respect to the mean FAA concentrations $\left(1070 \mathrm{fmol} \mathrm{m}^{-3}\right)$.

Any studies on the influence of the 2010 Eyjafjallajökull eruption in the Arctic region haven't been published yet, but some results have already been presented at meetings and conferences. At the $10^{\text {th }}$ Ny Alesund Seminar Kriews et al. 2011 showed a study on the chemical characterization of the volcanic plume at Spitsbergen (Svalbard Islands) at the ground level, in aerosol and depositions both, verifying strong differences in element concentrations and compositions before and after the volcano ash plume reached the sampling location.

Two other samples, 6-13 July and 24-31 August 2010 have FAA concentrations at or near $1500 \mathrm{fmol} \mathrm{m}^{-3}$ (Fig. 5). These samples do not appear to be influenced by specific sources, as their amino acid pattern is similar to the rest of samples. We detected the lowest amino acid concentrations during samples from the last three weeks of July and during September 7-14 sample. These low concentrations are mainly due to the lack of Gly, which accounted for at least $30 \%$ of the total FAAs in the other samples. The low FAA concentrations toward the end of the summer is consistent with the literature suggesting that during the Arctic summer regional aerosol concentrations are significantly less than boreal winter and spring concentrations (Quinn et al., 2007; Geng et al., 2010 and references within).

The wide range of amino acid reactivities can help determine atmospheric transport of particles (McGregor and Anastasio, 2001). Gly, for example, has a very low photochemical reactivity, with a half-life greater than 19 days in the aqueous phase (McGregor and Anastasio, 2001), and is generally considered as an indicator of long-lived aerosols (Matsumoto and Uematsu, 2005). In our samples, Gly occurred in 11 of the $17<0.49 \mu \mathrm{m}$ filters and was scarce in other aerosol size classes, so we hypothesize that mainly long-range aerosol transport affected the ultrafine FAA concentrations. Met is also used as an indicator of atmospheric transport. Met is rapidly destroyed by ozone in the atmosphere (half-life of $2.5 \mathrm{~h}$ ) producing MetSO (half-life of 21-80 h) that can be oxidized to $\mathrm{MetSO}_{2}$. Met/MetSO and $\mathrm{MetSO} / \mathrm{MetSO}_{2}$ are useful indicators of aerosol age over short to medium periods of time. Of the Met oxidation products, we only observed MetSO in 4 of the $<0.49 \mu \mathrm{m}$ background filters (1-7 and 13-19 May, 6-16 June, and 24-31 August). However, $\mathrm{MetSO}_{2}$, was under the limit of detection (LOD) in every sample. The mean Met/MetSO ratio was $0.4 \pm 0.1$ indicating the contribution of mid-distance ( $10 \mathrm{~s}$ to $100 \mathrm{~s}$ of $\mathrm{km} \mathrm{s}$ ) aerosol sources. Although Met and associated oxidation products are not identified as volcanic (Mukhin et al., 1978) or biomass burning products (Schmeltz and Hoffmann, 1977; Mace et al., 2003a), the observed sample Met/MetSO ratio suggesting mid-distance aerosol sources support our interpretation of the 1-7 and 13-19 May events.

We performed a cluster analysis on an autoscaled data matrix, using Ward's algorithm and Euclidean distances as clustering criteria to better understand possible relations between compounds and samples. We excluded the samples collected during 1-7 and 13-19 May from this analysis because they were affected by particular amino acid sources including volcanism and local fire activity, as previously described in this paper. Phe, Met, Asn, Asp, Cys and MetSO were < LOD in more than a half of the cases and therefore we excluded these amino acids from the cluster analysis. The tree dendrogram divided the variables into three groups at linkage distance 2 (Fig. 6). One group is composed by three relatively unreactive amino acids (Gly, Glu, Ala) where Gly and Glu have the lowest atmospheric reactivities in aqueous phase (half life of 85 and 19 days respectively) (McGregor and Anastasio, 2001) and Ala shows rarely reacts with .OH and other radicals (Milne and Zika, 1993). Gly is considered an indicator of long distance aerosol transport (McGregor and Anastasio, 2001) so the grouping of these amino acids likely represents a distant aerosol. This conclusion is supported by previous studies of Gly in the Venice lagoon (Barbaro et al., 2011). The cluster analysis creates another group from Ile, Leu, Thr that are all relatively reactive amino acids and their instability indicates a local or medium distant source (Milne and Zika, 1993). In addition, the concentrations of Leu and Ile $\left(r^{2}=0.92, p=0.00001\right)$, Leu and Thr $\left(r^{2}=0.93, p=0.00001\right)$, Leu and Phe $\left(r^{2}=0.91, p=0.0002\right)$ and Thr and Phe $\left(r^{2}=0.98, p<0.00001\right)$ are highly correlated, suggesting similar sources and atmospheric behavior. These compounds are present in coastal and marine phytoplankton and bacteria (Cowie and Hedges, 1992) and are released in Arctic Ocean surface water (Dittmar et al., 2001; Matrai et al., 2008).

The final group links the compounds Pro, Val, Ser, Tyr which are frequently found in terrestrial and marine aerosols (Mace et al., 2003a; Mader et al., 2004; Mandalakis et al., 2011; Violaki and Mihalopoulos, 2010; Zhang and Anastasio, 2003). These compounds have a variety of reactivities and may indicate a combination of various sources (plants, 
NOAA HYSPLIT MODEL

Backward trajectories ending at 0000 UTC 08 May 10 CDC1 Meteorological Data

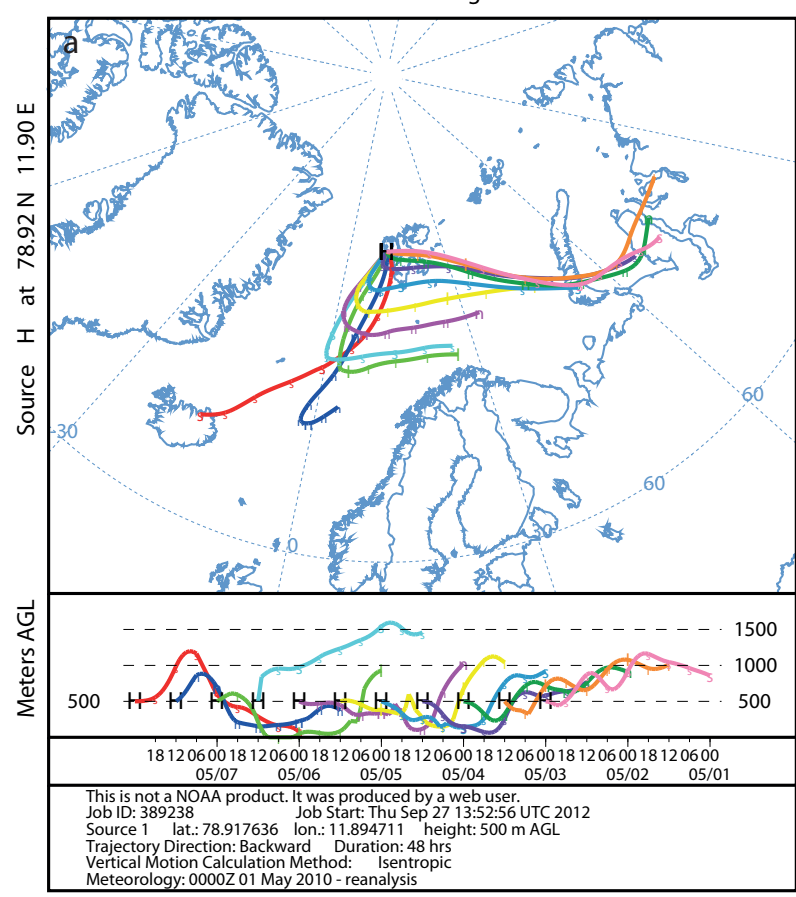

NOAA HYSPLIT MODEL

Backward trajectories ending at 0000 UTC 20 May 10 CDC1 Meteorological Data

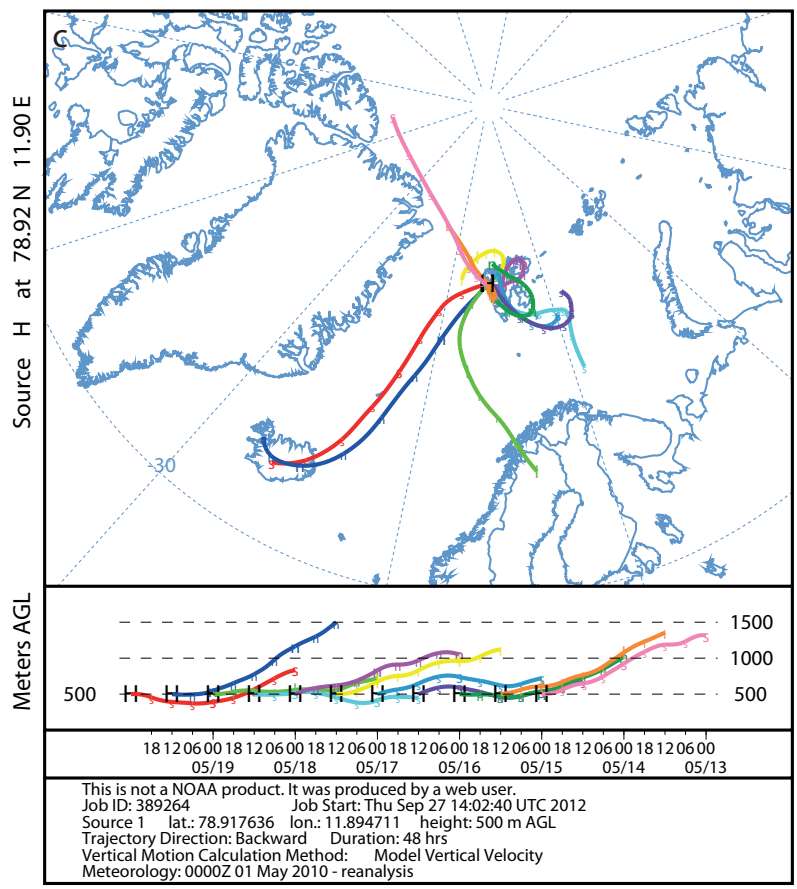

NOAA HYSPLIT MODEL

Backward trajectories ending at 0000 UTC 14 May 10

CDC1 Meteorological Data

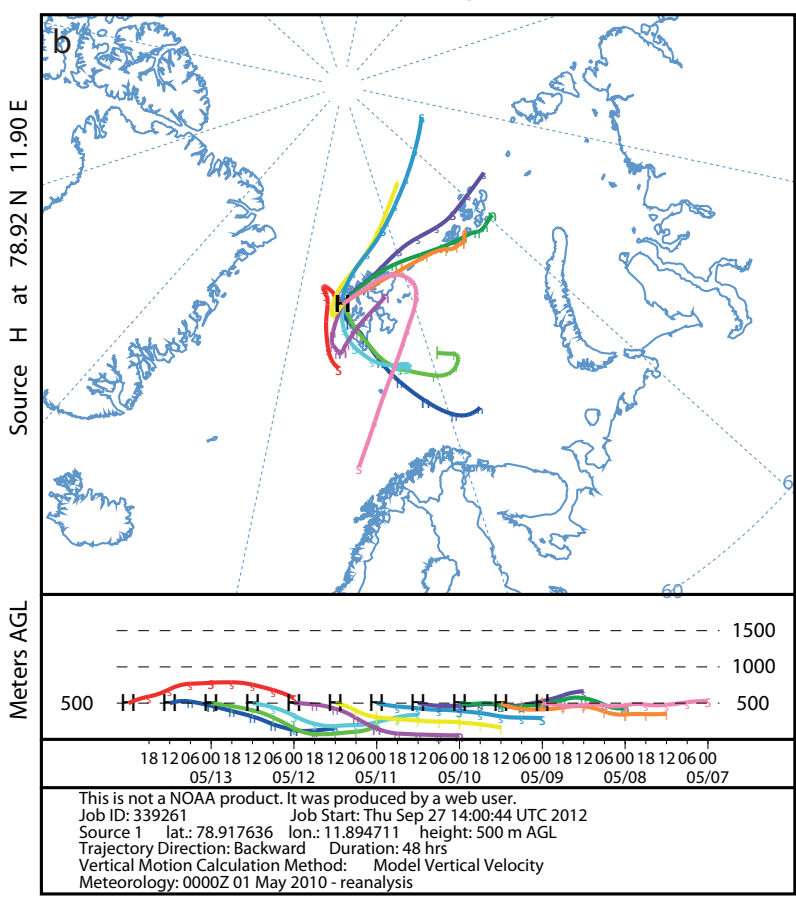

NOAA HYSPLIT MODEL

Backward trajectories ending at 0000 UTC 01 Jun 10 CDC1 Meteorological Data

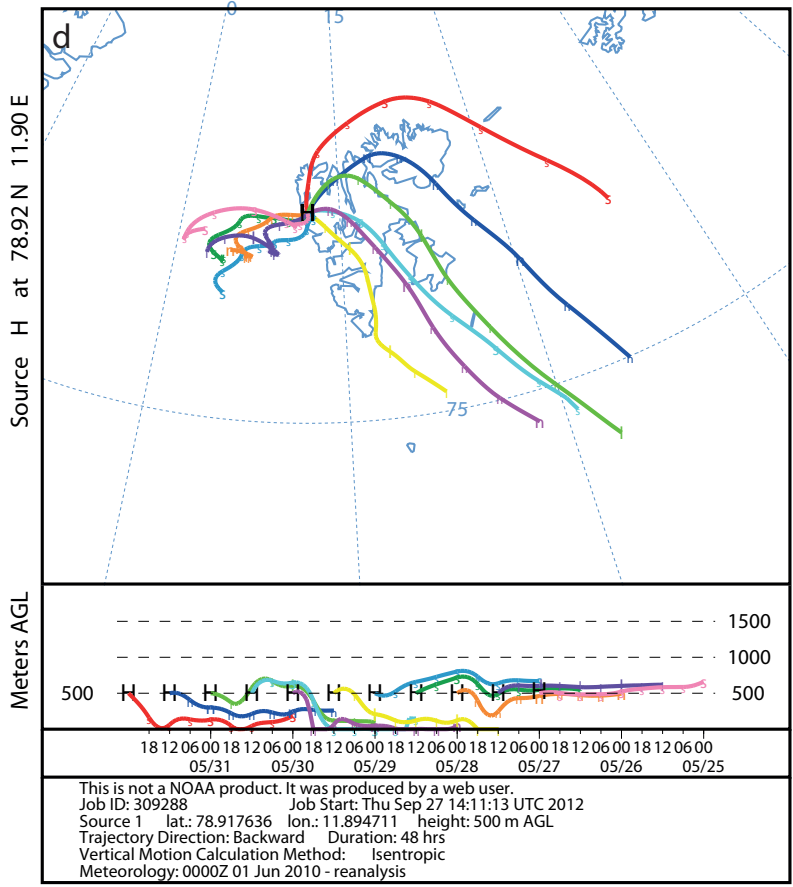

Fig. 4. Back trajectories of the 1-7 May (a), 7-13 May (b), 13-19 May (c) and 25-31 May (d) samples collected during the eruption of the Eyjafjallajökull volcano. The $48 \mathrm{~h}$ back trajectories are calculated at $500 \mathrm{~m}$ for the entire sampling period, starting a new trajectory every 12 hours, with the NOAA HYSPLIT trajectory model from the NOAA ARL website (http://www.arl.noaa.gov/ready/). We used the NCEP/NCAR Reanalysis meteorological database and the isentropic trajectories as they incorporate vertical transport components and integrate the vertical difference between the HYSPLIT model and the NCAR reanalysis data. 


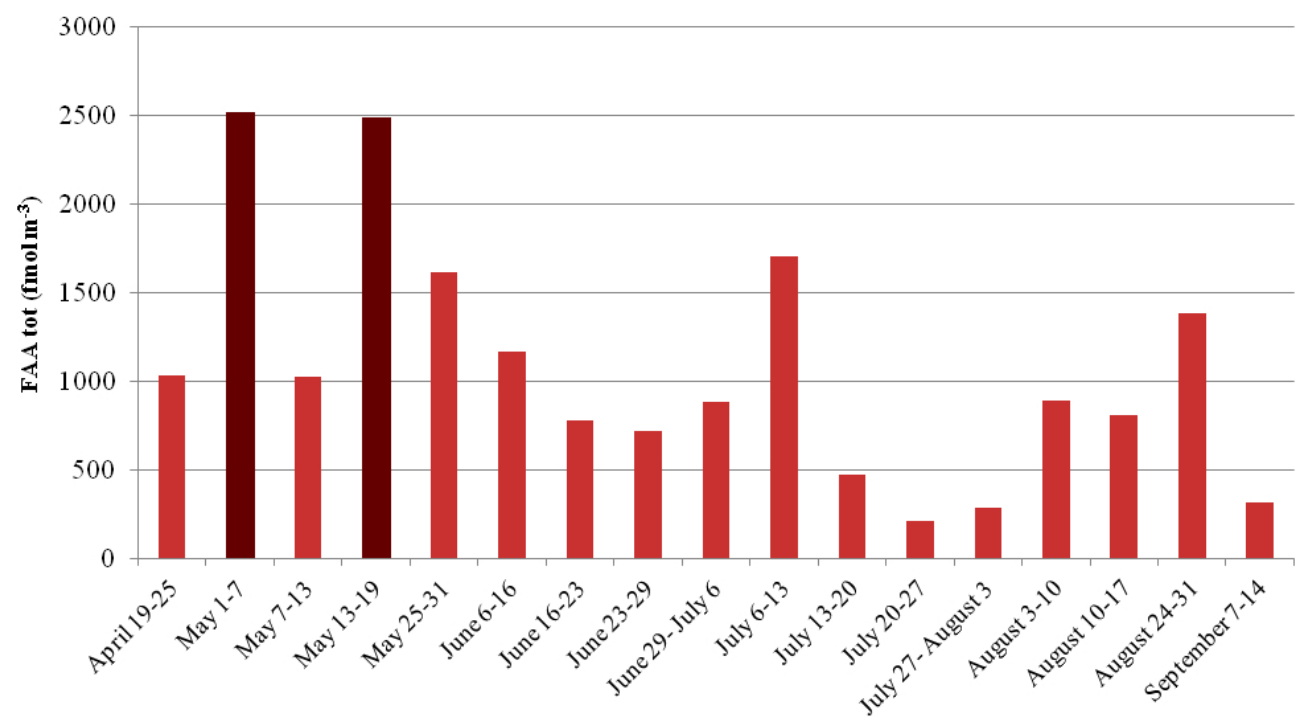

Fig. 5. Total amino acid concentrations in the $<0.49 \mu \mathrm{m}$ filters $\left(\mathrm{fmol} \mathrm{m}^{-3}\right)$ demonstrating the influence of local fires and regional volcanic activity in the samples from 1-7 and 13-19 May.

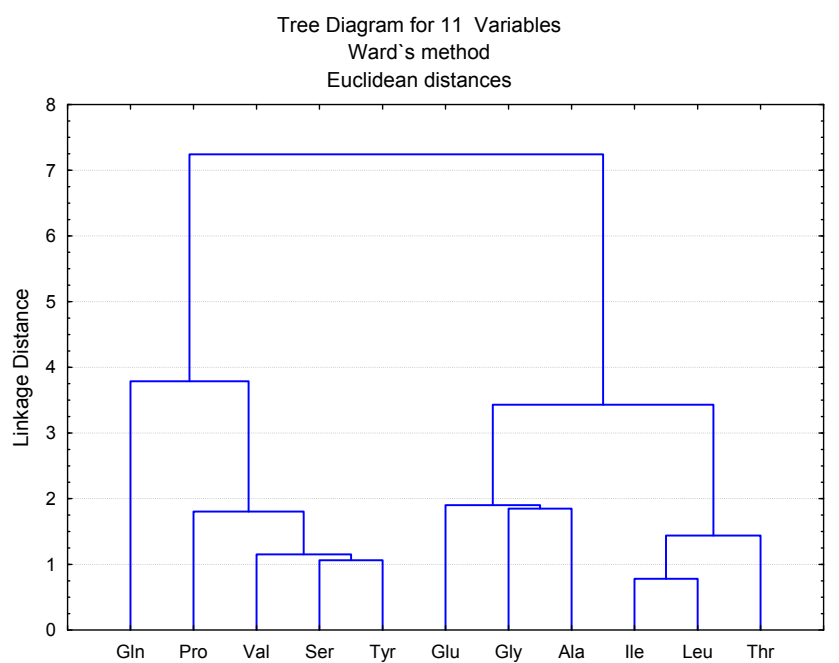

Fig. 6. Cluster analysis dendrogram for 11 amino acids.

pollen, bacteria, phytoplankton) or an influence of both longrange and locally-derived aerosols. Tyr and Ser are reactive and hydrophilic compounds, while Pro and Val are hydrophobic, so the relation between the four compounds appears to be more affected by source differences than by similar chemical behaviors.

A factor analysis confirms the cluster analysis results (Table 4) and explains $91 \%$ of the variance with three factors. The first factor demonstrates the major contribution from compounds deriving from various sources (Pro, Val, Ser, Tyr and Gln). Gln is not closely linked to these compounds, and may have a different source. Barbaro et al. (2011) suggested a photochemical origin of Gln from the oxidative attack of
Table 4. Factor loadings matrix after varimax rotation.

\begin{tabular}{lrrr}
\hline & Factor 1 & Factor 2 & Factor 3 \\
\hline Thr & 0.272522 & 0.922389 & 0.034151 \\
Leu & 0.301468 & 0.923230 & 0.046755 \\
Ile & 0.149178 & 0.961468 & 0.074335 \\
Tyr & 0.861509 & 0.451854 & 0.173175 \\
Val & 0.882489 & 0.301817 & 0.187296 \\
Pro & 0.916579 & 0.236036 & -0.030638 \\
Ala & 0.703670 & 0.458505 & 0.383041 \\
Glu & 0.071820 & 0.623605 & 0.613301 \\
Gln & 0.907161 & -0.189530 & -0.238929 \\
Ser & 0.901476 & 0.338429 & 0.113311 \\
Gly & 0.046770 & -0.009847 & 0.975583 \\
\hline
\end{tabular}

-OH radicals on peptides, leading to the formation of amides. The second factor links Ile, Leu and Thr which are derived from local or medium distant sources ( $10 \mathrm{~s}$ to $100 \mathrm{~s}$ of $\mathrm{km} \mathrm{s}$ ) and the third factor is dominated by Gly, which represents aerosol transported from distant sources ( $100 \mathrm{~s}$ of $\mathrm{km} \mathrm{s})$. The factor analysis does not definitively demonstrate the contribution of Glu as this amino acid has similar loadings in the second and third factor. Unlike in the cluster analysis, Ala is grouped in the first factor that contains amino acids from various sources. These results imply that Arctic aerosols are influenced by both local and long range transport, although sea surface bubble bursting processes likely contribute amino acids to Arctic aerosols.

The back trajectories (Figs. S1, S2, S3, S4) calculated for each sample during each of the sampling times (131$246 \mathrm{~h})$ verify that the collected aerosols originated primarily from marine areas including near the coasts of 
Greenland, northeastern Canada and the northern perimeter of the Eurasian landmass. Only one sample (6-13 July) might have a land-based origin (Fig. S2b), deriving from the Norway and Sweden coasts, while the other 16 samples demonstrate primarily marine origins. One of the major sources of amino acids in this area is likely the Arctic Ocean microlayer that is rich in bacteria, phytoplankton and organics including amino acids during the summer season (Dittmar et al., 2001; Matrai et al., 2008).

\section{Conclusions}

Total and single FAAs detected in polar aerosols collected in the Svalbard Islands from 19 April to 14 September 2010 provide evidence that considerable concentrations of FAAs occur in the summer Arctic atmosphere. Total FAA concentrations ranged between $592 \mathrm{fmol} \mathrm{m}^{-3}$ and $4953 \mathrm{fmol} \mathrm{m}^{-3}$ with serine and glycine as the dominant compounds, accounting for $45-60 \%$ of the total FAA content. The ultrafine aerosol fraction $(<0.49 \mu \mathrm{m})$ accounted for the majority of the total amino acid content in most samples. Two events resulted in weekly FAA concentrations more than double the mean FAA concentration for the rest of the summer. Samples collected during 1-7 and 13-19 May 2010 had total FAA concentration near $2500 \mathrm{fmol} \mathrm{m}^{-3}$ (Fig. 5) with substantially increased FAA concentrations in the large $(10-7.2 \mu \mathrm{m})$ and medium $(3.0-1.5 \mu \mathrm{m})$ size distributions. These concentration peaks are respectively due to local human-induced fires and regional volcanic activity.

Amino acids represent useful indicators for aerosol age and origin (Barbaro et al, 2011; Matsumoto and Uematsu, 2005). A cluster analysis and a factor analysis for the ultrafine aerosol samples suggest the contribution of two sources of amino acids in Arctic aerosols: (1) regional and long-range transport from marine areas and (2) the influence of local sources such as marine primary production. Back trajectory analyses support the conclusion of a mainly marine origin of the air masses transporting the FAAs. Our results suggest that the Arctic Ocean is a significant source of bioderived aerosol. Amino acids are important constituents of the Arctic microlayer and subsurface water and several authors reported the sea origin of atmospheric FAAs (Matrai et al., 2008; Wedyan and Preston, 2008). Numerical simulations demonstrate that the sea spray height and transfer of local sea spray aerosols to Svalbard depends on surface wind speeds (Doernbrack et al., 2010) suggesting that marine FAAs may increase during times of increase wind speeds.

Our novel amino acid results are consistent with the literature that suggests that Arctic summer aerosol chemical compositions are primarily affected by local to regional natural emission sources (Quinn et al., 2007) although many of these originally marine aerosols contain aged sea salts that have reacted with atmospheric $\mathrm{NOx}$ or $\mathrm{HNO}_{3}$ (Geng et al., 2010). Boreal winter aerosols are influenced by transported polluted air from the Eurasian landmass (Quinn et al., 2007) and future work should examine Arctic FAAs during winter and spring months to determine how this primarily anthropogenic input affects FAA concentrations in the seasonal Arctic haze.

\section{Supplementary material related to this article is available online at: http://www.atmos-chem-phys.net/12/ 10453/2012/acp-12-10453-2012-supplement.pdf.}

Acknowledgements. This work was supported by funding to the National Research Council of Italy (CNR) and the EarlyHumanImpact ERC Advanced Grant from the European Commission's VII Framework Programme, grant number 267696; this is EarlyHumanImpact contribution number 2 . The authors also gratefully acknowledge the help of ELGA LabWater in providing the PURELAB Option-R and Ultra Analytic, which produced the ultra-pure water used in these experiments.

Edited by: R. Ebinghaus

\section{References}

Barbaro, E., Zangrando, R., Moret, I., Barbante, C., Cescon, P., and Gambaro, A.: Free amino acids in atmospheric particulate matter of Venice, Italy, Atmos. Environ., 45, 5050-5057, 2011.

Chan, M. N., Choi, M. Y., Ng, N. L., and Chan, K. C.: Hygroscopicity of Water-Soluble Organic Compounds in Atmospheric Aerosols: Amino Acids and Biomass Burning Derived Organic Species, Environ. Sci. Technol., 39, 1555-1562, 2005.

Cornell, S., Jickells, T., Cape, J. N., Rowland, A., and Duce, R.: Organic nitrogen deposition on land and coastal environments: a review of methods and data. Atmos. Environ., 37, 2173-2191, 2003.

Cowie, L. and Hedges, J. I.: Sources and reactivities of amino acids in a coastal marine environment, Limnol. Oceanogr., 37, 703724, 1992.

De Haan, D., Corrigan, A., Smith, K., Stroik, D., Turley, J., Lee, F. E, Tolbert, M. A., Jimenez, J. J., Cordova, K. E. and Ferrell, G. R.: Secondary organic aerosol-forming reactions of glyoxal with amino acids, Environ. Sci. Technol., 43, 2818-2824, 2009.

Dittmar, T., Fitznar, H. P., and Kattner, G.: Origin and biogeochemical cycling of organic nitrogen in the eastern Arctic Ocean as evident from -D and -L amino acids, Geoch. Cosmoch. Acta, 65, 4103-4114, 2001.

Dörnbrack, A., A., Stachlewska, I. S., Ritter, C., and Neuber, R.: Aerosol distribution around Svalbard during intense easterly winds, Atmos. Chem. Phys., 10, 1473-1490, doi:10.5194/acp10-1473-2010, 2010.

Ge, X., Wexler, A. S., and Clegg, S. L.: Atmospheric amines - Part I: A review, Atmos. Environ., 45, 524-546, 2011.

Geng, H., Ryu, J., Jung, H.-J., Chung, H., Ahn, K.-H., and Ro, C.-U.: Single-particle characterization of summertime Arctic aerosols collected at Ny-Alesund, Svalbard, Environ. Sci. Technol., 44, 2348-2353, 2010. 
Gorzelska, K. and Galloway, J. N.:. Amine nitrogen in the atmospheric environment over the North Atlantic Ocean, Global Biogeochem. Cy., 4, 309-333, 1990.

Hillamo, R., Kerminen, V.-M., Aurela, M., Makela, T., Maenhaut, W., and Leck, C.: Modal structure of chemical mass size distribution in the high Arctic aerosol, J. Geophys. Res., 106, 2755527571, 2001.

Hawkins, L. N. and Russell, L. M.: Polysaccharides, Proteins, and Phytoplankton Fragments: Four Chemically Distinct Types of Marine Primary Organic Aerosol Classified by Single Particle Spectromicroscopy, Adv. Meteorol., 2010, 14 pp., 612132, doi:10.1155/2010/612132, 2010.

Kieber, R., Long, M., and Willey, J.: Factors influencing nitrogen speciation in coastal rainwater, J. Atmos. Chem., 52, 81-99, 2005.

Kriews, M.,Stölting, I., and Dick, D.: The Eyjafjallajökull eruptionChemical characterization of the ash plume at Spitsbergen-, Canas '11, Colloquium Analytical Atomic Spectroscopy, 13-16 March 2011, Helmholtz Centre for Environmental Research UFZ, Leipzig, 2011.

Kuznetsova, M., Lee, C., and Aller, J.: Characterization of the proteinaceous matter in marine aerosols, Mar. Chem., 96, 359-377, 2005

Leck, C. and Bigg, E.: Aerosol production over remote marine areas-a new route, Geophys. Res. Lett., 26, 3577-3580, 1999.

Leck, C. and Bigg, E.: Comparison of sources and nature of the tropical aerosol with the summer high Arctic aerosol, Tellus, 60B, 118-126, 2008.

MacDougall, D. and Crummett, W. B.: Guidelines for Data Acquisition and Data Quality Evaluation in Environmental Chemistry. Anal. Chem., 52, 2242-2249, 1980.

Mace, K. A., Artaxo, P., and Duce, R.: Water-soluble organic nitrogen in Amazon Basin aerosols during the dry (biomass burning) and wet seasons. J. Geophys. Res., 108, 4512-4522, 2003a.

Mace, K. A., Duce, A., and Tindale, N.: Organic nitrogen in rain and aerosol at Cape Grim, Tasmania, Australia, J. Geophys. Res., 108, 4338-4352, 2003b.

Mace, K. A., Kubilay, N., and Duce, R. A.: Organic nitrogen in rain and aerosol in the eastern Mediterranean atmosphere: An association with atmospheric dust, J. Geophys. Res., 108, 43204331, 2003c.

Mader, B. T., Yu, J. Z., Xu, J. H., Li, Q. F., Wu, W. S., Flagan, R. C., and Seinfeld, J.H.: Molecular composition of the water soluble fraction of atmospheric carbonaceous aerosols collected during ACE-Asia. J. Geophys. Res., 109, D06206, doi:10.1029/2003JD004105, 2004.

Mandalakis, M., Apostolaki, M. and Stephanou, E. G.: Trace analysis of free and combined amino acids in atmospheric aerols by gas cromatography-mass spectrometry, J. Chromatogr. A, 1217, 143-150, 2010.

Mandalakis, M., Apostolaki, M., Tziaras, T., Polymenakou, P., and Stephanou, E. G.: Free and combined amino acids in marine background atmospheric aerosol over the Eastern Mediterranean, Atmos. Environ., 45, 1003-1009, 2011.

Matrai, P. A., Tranvik, L., Leck, C., and Knulst, J. C.: Are high Arctic surface microlayers a potential source of aerosol organic precursors?, Mar. Chem., 108, 109-122, 2008.
Matsumoto, K. and Uematsu, M.: Free amino acids in marine aerosols over the western North Pacific Ocean. Atmos. Environ., 39, 2163-2170, 2005.

McGregor, K. G. and Anastasio, C.: Chemistry of fog waters in California's Central Valley: 2. Photochemical transformations of amino acids and alkyl amines, Atmos. Environ., 35, 1091-1104, 2001.

Milne, P. and Zika, R. G.: Amino acid nitrogen in atmospheric aerosols: occurrence, sources and photochemical modification, J. Atmos. chem., 16, 361-398, 1993.

Mukhin, L., Bondarev, V. B., and Safonova, E.: The role of volcanic processes in the evolution of organic compounds on the primitive earth. Mod. Geo., 6, 119-122, 1978.

Petersen, G. N.: A short meteorological overview of the Eyjafjallajökull eruption 14 April-23 May 2010, Weather, 65, 203-207, 2010.

Quinn, P. K., Shaw, G., Andrews, E., Dutton, G., Ruoho Airola, T., and Gong, S. L.: Arctic haze: current trends and knowledge gaps. Tellus, 59, 99-114, 2007.

Scheller, E.: Amino acids in dew - origin and seasonal variation. Atmos. Environ., 35, 2179-2192, 2001.

Schmeltz, I. and Hoffmann, D.: Nitrogen-containing compounds in tobacco and tobacco smoke. Chem. Rev., 77, 295-311, 1977.

Szyrmer, W. and Zawadzki, I.: Biogenic and Anthropogenic Sources of Ice-Forming Nuclei: A Review, B. Am. Meteor. Soc., 78, 209-228, 1997.

Violaki, K. and Mihalopoulos, N.: Water-soluble organic nitrogen (WSON) in size-segregated atmospheric particles over the Eastern Mediterranean, Atmos. Environ., 44, 4339-4345, 2010.

Wedyan, A. M. and Preston, R. M.: The coupling of surface seawater organic nitrogen and the marine aerosol as inferred from enantiomer-specific amino acid analysis, Atmos. Environ., 42, 8698-8705, 2008.

Weinbruch, S., Wiesemann, D., Ebert, M., Schütze, K., Kallenborn, R., Ström, J.: Chemical composition and sources of aerosol particles at Zeppelin Mountain (Ny Ålesund, Svalbard): An electron microscopy study. Atmos Environ., 49, 142-150, 2012.

Yang, H., Yu, J. Z., Ho, S. S., Xu, J., Wu, W. S., Wan, C. H., Wang, X., Wang, X. and Wang, L.: The chemical composition of inorganic and carbonaceous materials in $\mathrm{PM}_{2.5}$ in Nanjing, China, Atmos. Environ., 39, 3735-3749, 2005.

Zangrando, R., Piazza, R., Cairns, W., Izzo, F. C., Vianello, V., Zendri, E., and Gambaro, A.: Quantitative determination of un-derivatized amino acids in artistic mural paintings using high-performance liquid chromatography/electrospray ionization triple quadrupole mass spectrometry, Anal. Chim. Acta, 675, 1-7, 2010.

Zhang, Q. and Anastasio, C.: Chemistry of fog waters in California's Central Valley - Part 3: concentrations and speciation of organic and inorganic nitrogen, Atmos. Environ., 35, 5629-5643, 2001.

Zhang, Q. and Anastasio, C.: Free and combined amino compounds in atmospheric fine particles $\left(\mathrm{PM}_{2.5}\right)$ and fog waters from Northern California, Atmos. Environ., 37, 2247-2258, 2003.

Zhang, Q., Anastasio, C., and Jimenez-Cruz, M.: Water-soluble organic nitrogen in atmospheric fine particles $\left(\mathrm{PM}_{2.5}\right)$ from northern California. J. Geophys. Res., 107, 4112-4121, 2002. 